\title{
Growth validation of gold coral Gerardia sp. in the Hawaiian Archipelago
}

\author{
Frank A. Parrish ${ }^{1, *}$, E. Brendan Roark ${ }^{2}$ \\ ${ }^{1}$ Pacific Islands Fisheries Science Center, National Marine Fisheries Service, 2570 Dole Street, Honolulu, Hawaii 96822, USA \\ ${ }^{2}$ Department of Geography, Texas A \& M University, College Station, Texas 77843-3147, USA
}

\begin{abstract}
Colonies of the Hawaiian gold coral Gerardia sp. ( $\mathrm{n}=48$ ) were measured, marked and then revisited 1 to $9 \mathrm{yr}$ later to look for evidence of linear growth. The video images showed no change in the proportional size of the coral colonies relative to the marker pots left on the bottom and no change in the pattern of distal branches. Few of the measured delta values exceeded the error of our measurement technique, and the detected change in the sample was statistically indistinguishable from zero. Even though the temperature cycle in the coral beds appears seasonal, these observations indicate that gold coral growth is much slower than growth estimates derived from basal stem ring counts treated as annuli. The period of study was too short to effectively evaluate the validity of life span estimates from radiocarbon studies. The variability in radiocarbon data was assessed with broad sampling $(n=23)$ across study sites to reveal a mean life span of $950 \mathrm{yr}$ with an overall radial growth of $\sim 41 \mathrm{\mu m} \mathrm{yr}^{-1}$. Based on the calculation of a gross radiocarbon linear growth rate of $2.2 \pm$ $0.2 \mathrm{~mm} \mathrm{yr}^{-1}$, the sample colonies marked in the field would have grown $\sim 1.8 \mathrm{~cm}$ during the study period.
\end{abstract}

KEY WORDS: Deep-sea coral $\cdot$ Mark and remeasure $\cdot$ Parasite $\cdot$ Colonization $\cdot$ Precious coral Ring counts $\cdot$ Annuli $\cdot$ Radiocarbon dating

Resale or republication not permitted without written consent of the publishe

\section{INTRODUCTION}

Deep-sea corals are known to be a group of longlived species, prompting many questions about their life history and ecology (Grigg 1974a, Grange \& Goldberg 1992, Druffel et al. 1995, Roark et al. 2005, Sherwood et al. 2006, Tracey et al. 2007). The colonization, succession and community structure of deep-sea corals, as with any sessile marine organism, must be considered in the context of the organism's life span, and for this reason estimates of growth rates are of fundamental importance (Connell 1978). Some of the more extensive studies on deep coral growth rates have been conducted as part of the Hawaiian precious coral fishery. Species harvested in this fishery include shallow-water black coral Antipathes griggi (Opresko 2009), pink coral (Corallium secundum, Corallium regale and Corallium laauense) and gold coral Gerardia sp.. For these taxa, radial growth (center to outer edge of the basal stem) and linear growth (vertical change from base to tip) have been estimated by mark-remeasurement techniques (shallow-water black coral) (Grigg 1965) and counting what were assumed to be annual skeletal growth rings in the colony stem (pink and gold coral) (Grigg 1974b, 2002). Recent comparison of findings from these methods to growth rates from radiocarbon dating of the Hawaiian precious corals showed good to rough agreement for the shallow-water black corals and the deeper pink corals, but large disparities (orders of magnitude) in the radial growth rates and life spans for gold coral (Roark et al. 2006). The growth estimates from stem ring counts of gold coral generate a $1 \mathrm{~mm} \mathrm{yr}^{-1}$ radial growth equivalent to a $6.6 \mathrm{~cm} \mathrm{yr}^{-1}$ linear growth for a maximum life span of roughly 70 yr (Grigg 2002). Radial growth estimates from radiocarbon $\left({ }^{14} \mathrm{C}\right)$ analyses of 5 samples of Hawaiian gold corals (some dead) range from 15 to $45 \mu \mathrm{m} \mathrm{yr}^{-1}$, with projected life spans ranging from 450 to $2740 \mathrm{yr}$ (Roark et al. 2006). The results of these radiometric tests are consistent with an earlier radio- 
metric dating of one Atlantic specimen of gold coral that had a life span of $\sim 1800$ yr ( $\pm 300 \mathrm{SE}$ ) (Druffel et al. 1995). The dating of the same specimen using amino acid techniques resulted in an estimated maximum life span of 250 yr ( $\pm 70 \mathrm{SE}$ ) (Goodfriend 1997). Based on this information, scientists (and resource managers) are confronted with 2 competing hypotheses of growth for gold coral: slow growth and very slow growth.

In the present study, we quantified growth in gold coral colonies that had been measured and marked in the field and then remeasured 1 to $9 \mathrm{yr}$ later. The observed change over time was then considered in relation to published estimates based on stem ring counts (slow growth) and radiocarbon analyses (very slow growth). Data loggers were used to monitor temperature cycles and additional samples of gold coral were collected at the study sites to better assess the variability in the radiocarbon growth estimates.

\section{MATERIALS AND METHODS}

In 2007, dives by the Hawaii Undersea Research Laboratory submersibles 'Pisces V' and 'Pisces IV' were conducted at 6 study sites where gold coral colonies had been identified, videotaped and their heights recorded in prior years (Fig. 1). The sites were spread across 5 degrees of latitude varying in seascape and seafloor topography (Table 1). Some of the coral beds grew on summits of seamounts and others on the slopes of islands or shallow banks. Gold coral is a hexacoral in the order Zoanthidea, and forms a proteinbased skeleton that can grow into large fans of more than $2 \mathrm{~m}$ in height. These gold coral 'trees' (Fig. 2A) grow on slopes between 300 and $500 \mathrm{~m}$ in depth and are suspension feeders that rely on passively collected organic particles and microplankton from the water column. Gold coral is parasitic in nature, found colo-

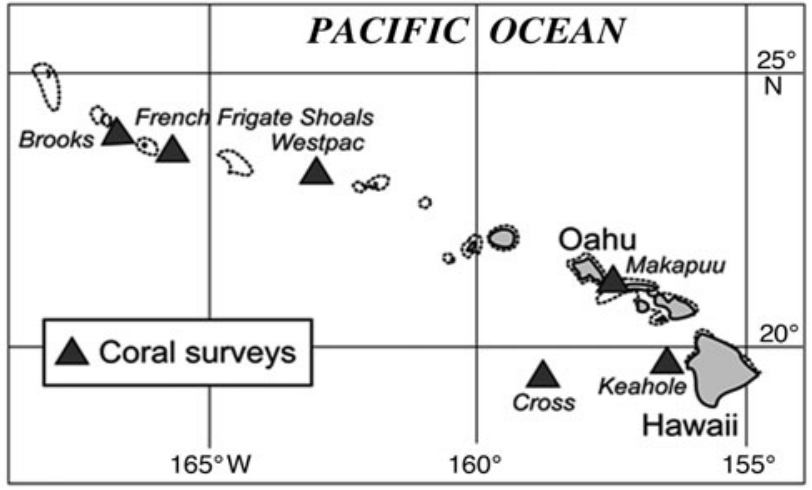

Fig. 1. Southern Hawaiian Archipelago with 6 study sites where gold corals were marked in the field and samples for radio carbon analyses were collected

nizing other coral colonies, especially bamboo coral (Isididae), where the gold coral spreads out and encases the entire bamboo coral colony forming branches that extend well beyond those of the host colony (Roark et al. 2006).

Marked field colonies. Gold colonies were videotaped, measured and marked opportunistically between 1998 and 2006 on submersible dives focused on the study of coral and fish assemblages at the 6 sites (Parrish et al. 2002, Parrish 2006, 2007). Initial measurements of the coral colonies were conducted using a calibrated laser scale projected on the colony for reference. Marked colonies ranged in size from 10 to $250 \mathrm{~cm}$ height, enabling us to examine any differences in growth associated with the maturity of the colony (Fig. 3). The overall height was measured for all colonies. Where possible, widths were taken and on larger colonies $(>100 \mathrm{~cm}$ ) some branch lengths were measured. Colony location was recorded using GPS-based slant range positioning from the submersible support vessel. Natural landmarks or placement of numbered concrete flower pots (Fig. 2A)
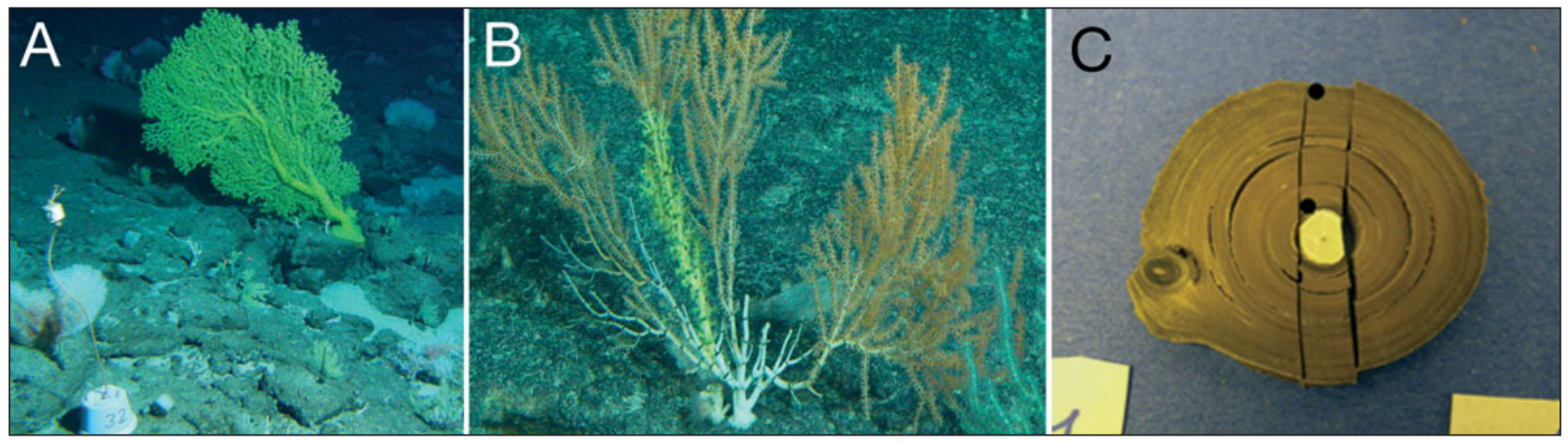

Fig. 2. (A) Gerardia sp. and Isidella sp. Gold coral colony marked with pot 32 for remeasurement. (B) Bamboo coral in the early stages of colonization by gold coral. The internodes of the bamboo skeleton are visible through the gold coral tissue (yellow-gold color), indicating the gold coral has not yet formed a protein skeleton. (C) Disk of gold coral used for radiocarbon sampling. Black circles denote where inner and outer radiocarbon samples were taken using a $0.5 \mathrm{~mm}$ diameter drill bit. Note the bamboo coral at the center that the gold coral overgrew. Underwater photos courtesy of Hawaii Undersea Research Laboratory 
Table 1. Location, depth, topography and the range of elapsed years between measurements of the colonies $(\mathrm{N})$

\begin{tabular}{|lclcc|}
\hline Study site & $\begin{array}{c}\text { Depth } \\
(\mathrm{m})\end{array}$ & Topography & $\mathrm{N}$ & $\begin{array}{c}\text { Years } \\
\text { elapsed }\end{array}$ \\
\hline Makapuu Point & $391-415$ & Island slope & 16 & $1-6$ \\
French Frigate Shoals & $351-354$ & Seamount & 27 & $6-9$ \\
Brooks Bank & $448-466$ & Bank slope & 11 & 9 \\
Westpac Seamount & $387-430$ & Seamount & 6 & $7-9$ \\
Cross Seamount & $388-392$ & Seamount & 5 & $5-7$ \\
Keahole Point & $380-400$ & Island slope & 5 & 7 \\
\hline
\end{tabular}

were used to verify the colony's identity and serve as a reference for quantification of proportional change in the colony over time.

The elapsed time between the initial measurements and the 2007 follow-up visit ranged from 1 to $9 \mathrm{yr}$ (Table 1). Photos and video of the colonies from the initial visit were used to conduct the follow-up appraisal from as similar an angle and distance as possible. The general shape and pattern of each colony's distal branches were checked for change, noting any differences in the presence of epiphytic, zoanthids and bare spots (portions of the colony without coral tissue). Measurements were made by the same individual who conducted the initial measurement without reviewing the data from the initial visit to limit observer bias. The difference, or delta value, between the initial and followup measurements comprised the data for comparisons. It was rarely possible to match the angle and distance used for the initial measurement, so the degree of error from the compromised viewing perspective must be

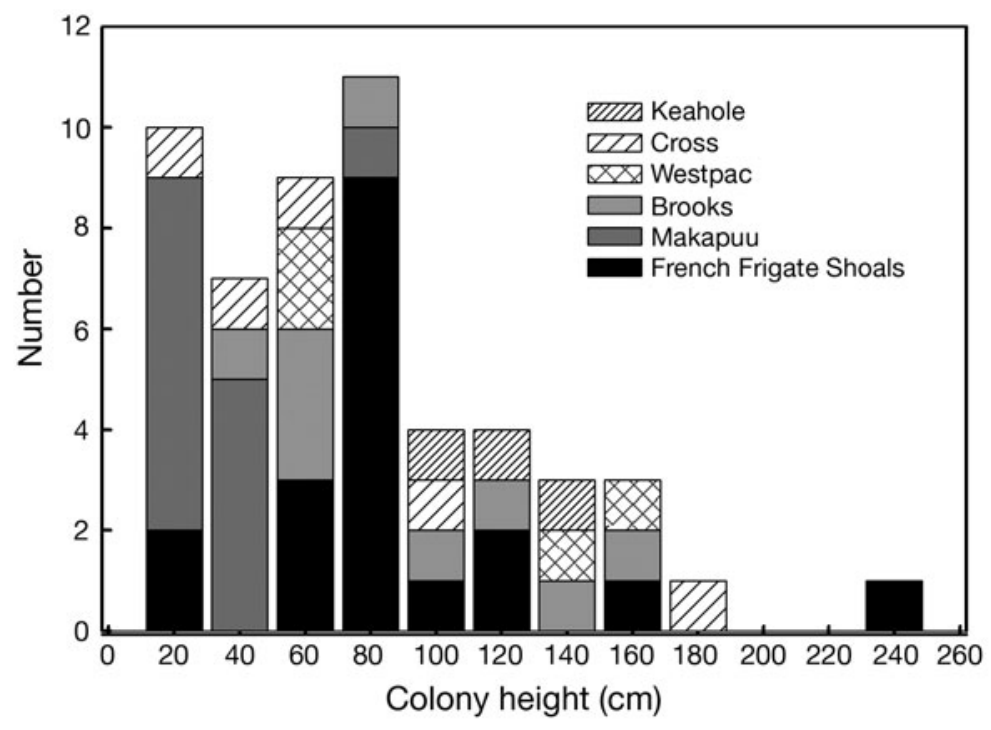

Fig. 3. Gerardia sp. Frequency (number) of colony heights binned into $20 \mathrm{~cm}$ categories by study site for gold corals colonies marked for remeasurement considered. Multiple measurements $(\geq 3)$ from different angles provided a crude estimate of overall measurement error at $\pm 9 \mathrm{~cm}$. If the viewing angle of the followup measurement was too severely compromised, the colony was dropped from the analysis.

As the coral colonies in the present study were marked opportunistically, the sample was non-normal and of unequal sizes. In all statistical comparisons, both parametric and non-parametric analyses were conducted and when there was agreement the parametric results were reported (Siegel \& Castellan 1988). Significance was set at the 0.05 level with the available sample affording a power of 0.80 at a large effect size (Cohen 1988).

Temperature and early colonization. Thermographs (Onset, Tidbit V2) were deployed and set to record a minimum of every $6 \mathrm{~h}$ at 3 of the gold coral sites (French Frigate Shoals, Cross Seamount and Makapuu Point; see Table 2) to track the temperature variability across the geographic range of the study. The profiles from the 3 sites were compared, looking for differences in mean temperature and a presence of a seasonal cycle that would provide an environmental signal that could be recorded as rings in the skeleton of the colony. To look for concordance in temperature profiles, the daily average from the coral bed was compared to daily sea surface temperature extracted from satellite data (GOES 0.1 degree resolution).

As none of the marked colonies included the settlement and initial colonization phases of gold coral growth, some effort on the 2007 surveys was spent looking for colonies of bamboo coral hosts in the early stages of colonization by gold coral.

Radiocarbon samples. A total of 23 Gerardia sp. specimens, including pruned branches from living specimens, subfossil basal attachment stumps and fallen branches, were collected from the same deep-sea coral beds as the marked colonies with the exception of the Westpac site. Radiocarbon results for specimens ( $\mathrm{n}=17$ ) collected at Keahole Point (Hawaii Island), Lanikai and Makapuu Point deep-sea coral beds (Oahu) and Cross Seamount were reported in Roark et al. (2006, 2009) with detailed methods. An additional 6 specimens from current and previous collections at Brooks Bank $(\mathrm{n}=3)$, French Frigate Shoals ( $\mathrm{n}=2$ ) and Lanikai deep-sea coral beds $(n=1)$ are included here in order to provide radiocarbon data on specimens from as many sites as possible (Appendix 1). 
The same sampling protocols as previously reported in more detail by Roark et al. $(2006 ; 2009)$ were followed for the new specimens. Briefly, for the few samples from live individuals $(n=3)$, the external polyps and tissue were removed and subsamples were airdried prior to transfer to microcentrifuge vials. On removal of the tissue layer, the proteinaceous skeleton was washed with seawater and freshwater and allowed to air-dry on deck. Stumps and branches were cut into $\sim 0.7 \mathrm{~cm}$ thick cross-sectional disks. Complete Gerardia sp. disks taken closest to the basal attachment were used most often for ${ }^{14} \mathrm{C}$ sampling. Cursory sampling of the skeleton was performed by drilling $\sim 1$ to $4 \mathrm{mg}$ of material from the center (inner), middle and outer portions along a radial transect on a crosssectional disk.

For all radiocarbon samples, proteinaceous and tissue samples were treated with weak $\mathrm{HCl}$ to remove any carbonate material, copiously rinsed with Milli-Q water and dried. Samples were converted to $\mathrm{CO}_{2}$ by combustion in a sealed tube. The $\mathrm{CO}_{2}$ was then cyrogenically purified and reduced to graphite in the presence of an iron catalyst and a stoichiometric excess of hydrogen. Graphite targets were analyzed at the Center for Accelerator Mass Spectrometry, Lawrence Livermore National Laboratory, Livermore, California. Radiocarbon results are presented as $\Delta^{14} \mathrm{C}(\%)$ and conventional ages (Stuiver \& Polach 1977) and include a $\delta^{13} \mathrm{C}$ correction and a blank subtraction based on analysis of ${ }^{14} \mathrm{C}$-free coal. Analytical uncertainty was 3 to $4 \%$ or 30 to $40{ }^{14} \mathrm{C}$ yr for most Holocene samples. Conventional ${ }^{14} \mathrm{C}$ ages are converted to calendar years using a reservoir age of $380{ }^{14} \mathrm{C}$ yr $\left(\Delta \mathrm{R}\right.$ of $-28 \pm 23{ }^{14} \mathrm{C}$ yr) (Druffel et al. 2001) and Calib v5 (Hughen et al. 2004, Stuiver \& Reimer 1993) (Table A1). The resulting median probability age was used to calculate the life span of the specimens which was then used to calculate the radial growth rate by dividing the measured radial distance between the outerand innermost radiocarbon sample by the calculated life span.

\section{RESULTS}

\section{Marked field colonies}

Dives successfully revisited 48 colonies, resulting in 70 measurements to compare with values from the initial visit. The overall height of the colonies relative to the marker pots did not change between the initial and follow-up visits, suggesting little growth. No obvious change in the shape profiles of the distal branches was seen when the colonies were compared to the video from the initial visit. Even zoanthids that were recorded growing on the colony in previous years appeared the same. Two colonies had sustained obvious physical damage to the skeletal structure and these measurements were not included in the growth comparison analysis. The dispersion of the measured differences between initial and follow-up dives included both positive $(n=27)$ and negative $(n=19)$ values clustered around the zero axes (Fig. 4). Zero change was recorded for 23 cases, i.e. the initial and follow-up measurements were identical. The bulk of the sample $(87 \%)$ did not exceed the $\pm 9 \mathrm{~cm}$ measurement error. Most of the colonies (77\%) were revisited $>5$ yr since initial measurement. Normalizing the delta values by the years elapsed yielded an overall mean $( \pm \mathrm{SD})$ for the sample (including negative values) of $0.23 \pm 1.9 \mathrm{~cm} \mathrm{yr}^{-1}$. Normalized delta values showed no correlation with the initial size of the colonies, revealing no size-specific differences in the detection of change (Pearson, $\mathrm{r}=-0.114, \mathrm{p}=$ 0.349). There was also no growth-related pattern evident in a comparison of the 6 sites other than a notable negative mean value for Cross Seamount (ANOVA, adjusted $\mathrm{R}^{2}=-0.011, F=-0.229, \mathrm{p}=$ 0.634). Finally, the mean of the measured differences of the sample (normalized or not) were statistically indistinguishable from zero $(t=1.045 \mathrm{df}=69$, $\mathrm{p}=0.300)$.

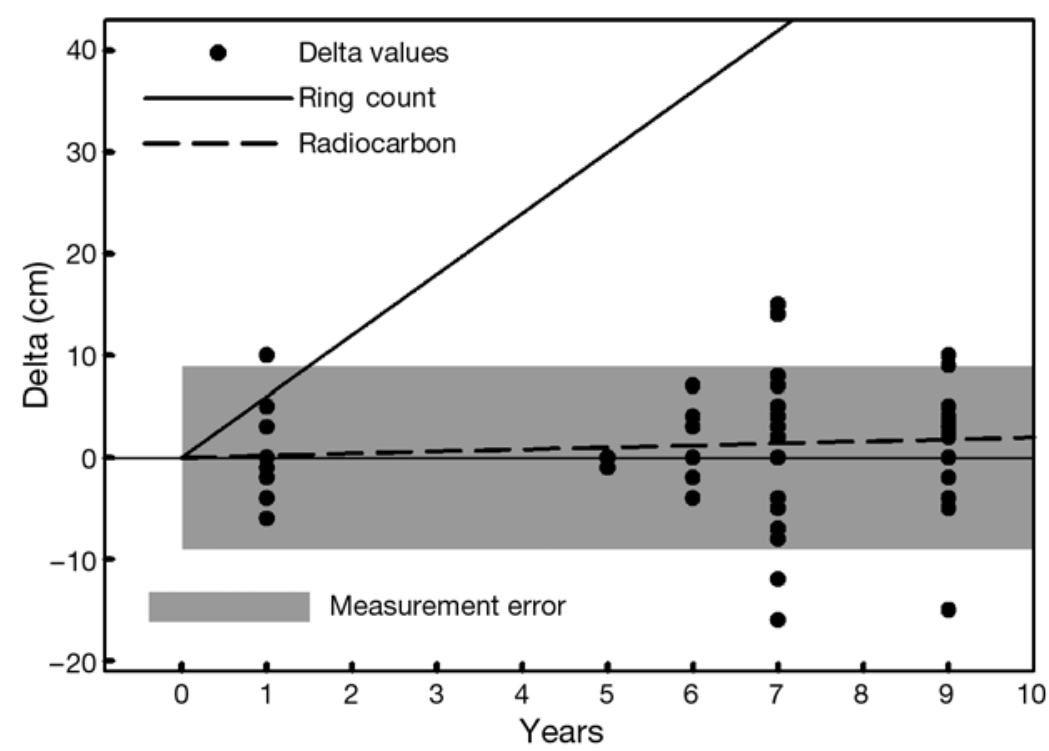

Fig. 4. Plot of the 2007 measured differences with the projected linear change based on stem ring counts and radio carbon analyses. The measurements fall short of the ring count projection and cluster around zero, with many negative measurements. The gray band indicates the measurement error 


\section{Temperature}

There were obvious differences in the temperature records from the 3 sites monitored with data loggers (Fig. 5). The oscillations of the profile at the Makapuu Point site deviated less than the other 2 sites. The French Frigate Shoals site was $2^{\circ} \mathrm{C}$ warmer than the mean temperature at the Makapuu Point and Cross Seamount sites. No significant differences in measured differences between the sites could be attributed to temperature (ANOVA, $F=0.548, \mathrm{df}=2$, $p=0.582$ ). The temperature profiles from the coral beds compared to satellite-derived sea surface temperature records were correlated at a low level despite the differences in the scale of oscillation between the profiles (Table 2). In situ temperature records from the French Frigate Shoals site were more strongly correlated to the seasonal change in the surface waters because of the region's greater seasonal fluctuations.

\section{Radiocarbon}

Radiocarbon analyses and conversion of ${ }^{14} \mathrm{C}$ years to calendar years (Stuiver \& Braziunas 1993) of outer and

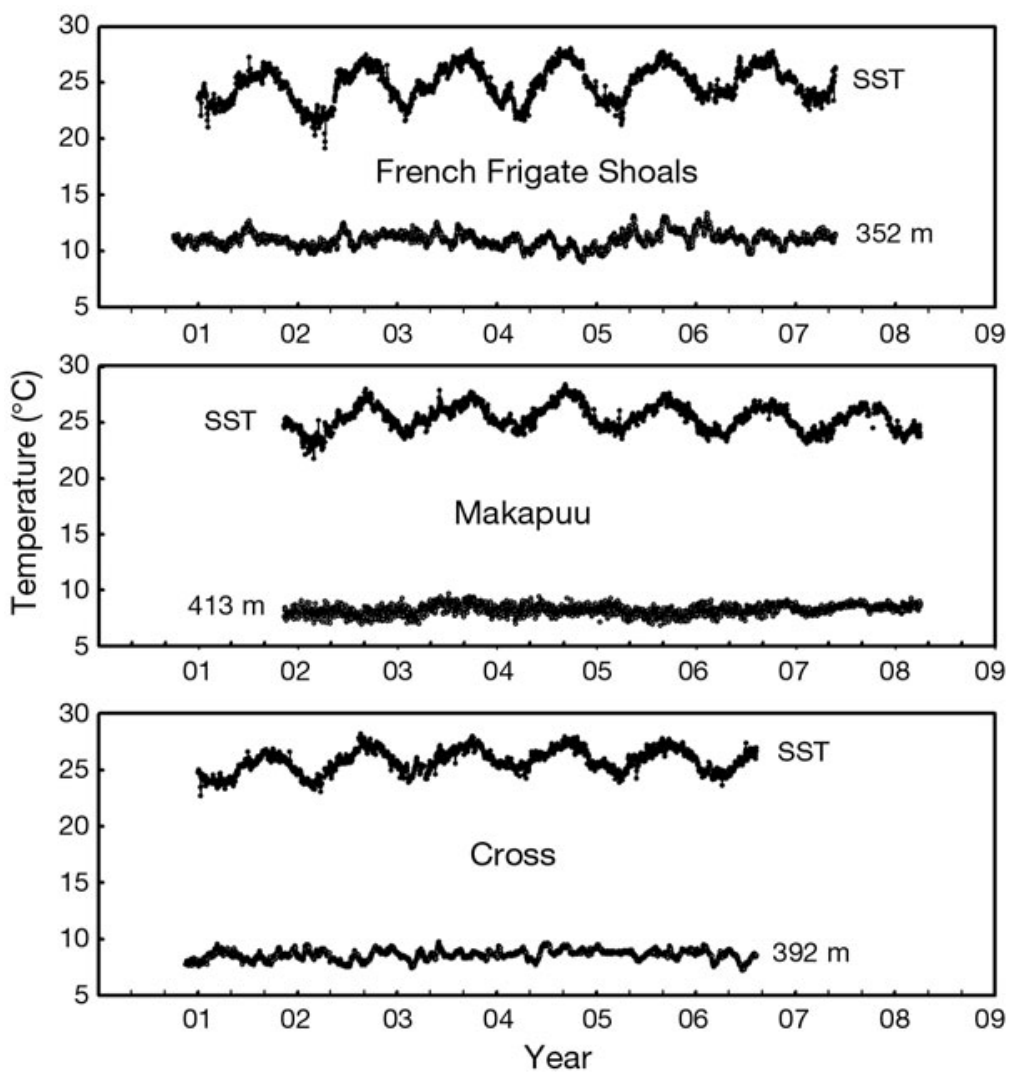

Fig. 5. Bottom and sea surface temperature (SST) records collected near gold coral colonies at 3 of the study sites showing the seasonal thermal cycle inner samples from a suite of cross sections cut from sub-fossil Gerardia sp. specimens allowed us to calculate radial growth rates and project life spans of a larger sample pool than previously published (Roark et al. 2006, 2009). The average $( \pm \mathrm{SE})$ radial growth rate was $41 \pm 23 \mu \mathrm{m} \mathrm{yr}^{-1}(\mathrm{n}=23)$ with a range of 11 to $84 \mu \mathrm{m}$ $\mathrm{yr}^{-1}$ (Fig. 6). The average life span of the analyzed specimens was $950 \mathrm{yr}$ and ranged from $\sim 300 \mathrm{yr}$ for a small branch (radius $=11 \mathrm{~mm}$ ) to $\sim 2700 \mathrm{yr}$ (radius $=38 \mathrm{~mm}$ ). The uncertainty of individual radial growth rate estimate depends on the uncertainty in the radial distance measurement, conservatively estimated at $\pm 0.5 \mathrm{~mm}$, and the uncertainty of the specimen's life span. The uncertainty in the life span primarily depends on the uncertainty in the calibrated radiocarbon age, which is not uniform about the median probability age and varies at different points along the calibration curve. In the present study, calibrated radiocarbon uncertainties averaged $60 \mathrm{yr}$ and ranged between 30 and 140 yr. Taking the least mean square uncertainty of $60 \mathrm{yr}$ for median probability ages of the outer and inner sample resulted in an average uncertainty of $\pm 85 \mathrm{yr}$ for the life span of a specimen and, combining that with the distance measurement uncertainty, we calculated an average uncertainty of only $\pm 4 \mu \mathrm{m} \mathrm{yr}^{-1}$ in the radial growth rate measurements. There may be a slight correlation between radial distance as a proxy for size and growth rate (Fig. 7). The correlation between faster radial growth rates and remote locations such as Cross Seamount, Brooks Bank and French Frigate Shoals appears to be stronger, but in both cases the sample size is too small to draw any firm conclusions (Fig. 7). The very slow radial growth rates and long life spans were consistent across the 6 survey sites where samples were collected.

\section{Colonization of bamboo coral}

Ten colonies of bamboo coral were found partially colonized by gold coral and they 


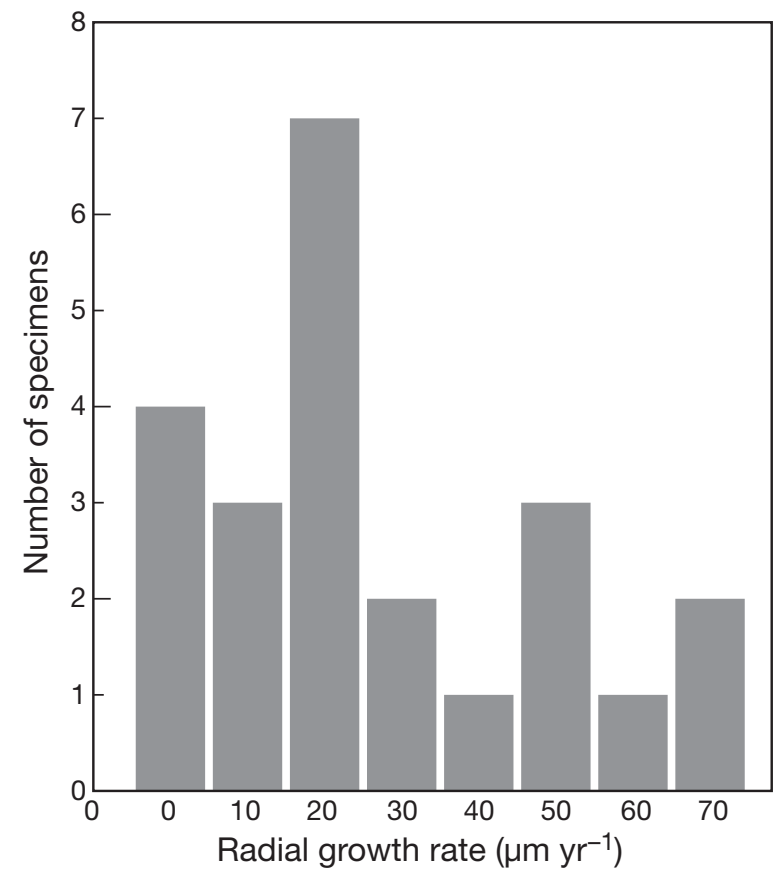

Fig. 6. Gerardia sp. Gold coral radial growth rates $\left(\mu \mathrm{m} \mathrm{yr}^{-1}\right)$ based on ${ }^{14} \mathrm{C}$ results showing average $( \pm \mathrm{SE})$ radial growth at $41 \pm 23 \mu \mathrm{m} \mathrm{yr}^{-1}(\mathrm{n}=23)$

were marked for future inspection. Eight of the bamboo colonies had been encrusted with gold coral from their base to mid-height. Two bamboo colonies were encrusted centrally, with gold coral not yet encrusting the base. In most cases, the gold coral portion was uniformly opaque, indicating the presence of a protein skeleton under the tissue. The 2 gold coral colonies that had colonized the central portion of the bamboo host were translucent. The nodes of the dead bamboo skeleton were clearly visible through the tissue of the

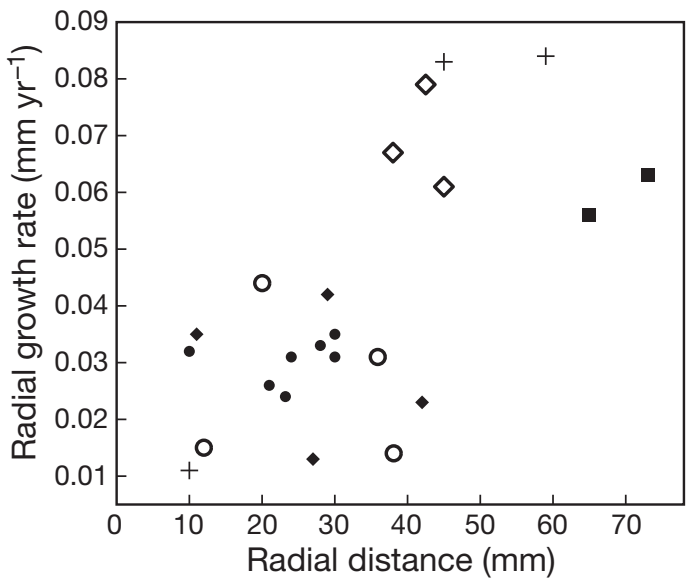

Fig. 7. Gerardia sp. Specimen size (radial distance) versus radiocarbon radial growth rate sorted by site: Keahole Point $(\bullet)$, Lanikai ( $\bullet$ ), Makapuu (০), Cross Seamount (+), Brooks Bank $(\diamond)$ and French Frigate Shoals (ם) gold colony suggesting no protein skeleton had yet been laid by the gold coral (Fig. 2B). The translucent gold coral tissue was evident over many centimeters with no obvious gold coral skeleton present. A large majority of the sub-fossil gold coral specimens collected for the radiocarbon work contained bamboo corals in the core, despite the fact that we could not be sure that the basal-most portion was collected in every case.

\section{DISCUSSION}

\section{Field validation technique}

On the follow-up dives it was readily apparent that the gold coral colonies were very slow growing. Comparing the colonies outside the view port to video images from initial dives viewed on the playback deck inside the sphere showed no change in the colonies' distal branch pattern or in their proportional size relative to the marker pots. The only change seen for certain was 2 colonies cropped from physical damage. The Brooks colony ( $25 \mathrm{~cm}$ initial height) was missing a small conspicuous lobe and a Cross Seamount colony ( $243 \mathrm{~cm}$ initial height) had a third of the colony sheared away. The reason for the loss of skeletal material is not known, but could include impacts from the submersible that we were unaware of (e.g. impacts from bumping into the colony or thruster wash). Other causes such as bioerosion, contact with other marine organisms such as passing sharks and or impacts from fishing gear are also possible. The Cross Seamount site had a lot of monofilament fishing gear on the seafloor and several gold coral colonies were seen entangled. Toppled large gold coral colonies are common and fall due to natural forces: corals grow large until the stress from the current on the surface area of the branches exceeds the strength of the holdfast, and then they topple. Once toppled, those unable to continue feeding die, and those where conditions are adequate for survival will continue to live for years and even add skeleton vertically over time.

The mark remeasurement technique has been used effectively to document growth of faster growing deep corals (Grigg 1965, Grange \& Goldberg 1992). Our appraisal of gold coral growth was limited by the relatively short period elapsed (9 yr) to discern change given the coral's very slow growth. At best, one might interpret some growth based on the higher positive values found at year 7 and above, but there was also a corresponding increase in negative values suggesting other factors may have inflated the measurement error. For example, the 9 delta values that exceed the $\pm 9 \mathrm{~cm}$ estimated error were from significantly larger colonies 
$(94 \pm 47 \mathrm{~cm}[\mathrm{SD}])$ than the remainder of the sample $(60.4 \pm 42 \mathrm{~cm}$; ANOVA, $F=4.83, \mathrm{df}=1, \mathrm{p}=0.03)$. Measurement error may have increased on dives that occurred during high tidal currents compromising the submersible's ability to hold station, thus introducing error, especially for large colonies where the laser scale must be stepped across the full height of the coral tree.

\section{Growth estimates}

Ring counts

The lack of appreciable change in the marked field colonies indicates growth is much slower than published estimates based on stem ring counts. The $6.6 \mathrm{~cm}$ $\mathrm{yr}^{-1}$ mean linear growth derived from ring-count data (Grigg 2002) should average $59 \mathrm{~cm}$ of accumulated growth in the field samples over the 9 yr period. Even accounting for the error in the measurement technique, an appreciable mean increase in the sample of field-marked colonies should exceed the $\pm 9 \mathrm{~cm}$ error in 2 to 3 yr. In all years (range $=-0.33$ to $1.9 \mathrm{~cm}$ ) the mean delta value closely resembled zero.

Ring-count data has been used to estimate growth for black corals Antipathes spp. (Goldberg 1991, Grange \& Goldberg 1992, Grigg 1974b) and independently confirmed by field surveys of population age frequency (Grigg 2002, 2004) and radiocarbon studies (Roark et al. 2006). For shallow Corallium rubrum samples from the Mediterranean, organic growth rings were shown to be annual, but growth rings due to different densities (petrographic method) in the same specimens were not (Marschal et al. 2004). Ring counts treated as annuli for the deeper Hawaiian Corallium species yielded growth estimates that were also supported by independent field surveys of age frequency (Grigg 1974a) and roughly corresponded (twice the rate) to growth estimates of radiometric analyses (Roark et al. 2006). Recent work interpreting growth rings in bamboo corals indicate they may be sub-annual (Roark et al. 2005, Tracey et al. 2007). Thus the assumption that growth rings are annual should be treated with a great deal of skepticism until the periodicity of those growth rings can be verified by independent dating techniques. This is certainly true in the case of Hawaiian gold corals.

The thermographs from the 3 study sites indicate the presence of an overall annual thermal cycle of warming and cooling that could be part of the environmental signal recorded by growth bands in the coral skeleton. Warm peaks do occur in winter months and periods of colder water are seen in summer that may or may not contribute to variability in ring formation and/or confound seasonal signals. Comparing bottom temperature profiles to sea surface temperature shows thermal cycles on the bottom are less pronounced. For this reason, stem ring formation at deeper depths may be less annual in periodicity than shallower corals. Environmental variability is unlikely to explain all of the difference seen in the growth estimates of gold coral given that Hawaiian Corallium spp. grow at the same depth as gold coral and the differences between ring counts and radiocarbon estimates are considerably less than for gold coral.

\section{Radiocarbon data}

The exceptionally long life spans generated by the radiocarbon estimates for gold coral are hard to imagine in an ecological context. Radiocarbon analyses of the samples collected at these dives better defined the variability in the range of ages but again indicated the average radial growth rate of gold coral was 3 orders of magnitude slower than the estimate derived from stem ring counts. These findings were consistent with results from prior radiocarbon studies (Druffel et al. 1995, Roark et al. 2006, 2009). Initially, there were notions that the growth discrepancy between the ring count estimates and radiocarbon age was due to the gold corals feeding on old dead carbon from the deep sea $\left({ }^{14} \mathrm{C}\right.$-free), resulting in anomalously old ${ }^{14} \mathrm{C}$ ages (Grigg 2002, Goodfriend 1997). Roark et al. (2009) showed that tissue samples and the outermost skeletal $\Delta^{14} \mathrm{C}$ values in a live gold coral specimen from Lanikai, Hawaii, were indistinguishable from surface water dissolved inorganic carbon $\Delta^{14} \mathrm{C}$ values. Additionally, high-resolution (100 $\mu \mathrm{m}$ interval) sampling over the outermost $3 \mathrm{~mm}$ of the same specimen collected at $400 \mathrm{~m}$ reproduced almost exactly a reconstructed surface 'bomb' ${ }^{14} \mathrm{C}$ curve. These results verified that this colony feeds on the youngest particulate organic matter that rains down from surface layers, rejecting the hypothesis that old dead carbon from the deep sea was interned in the skeleton making it appear older than its

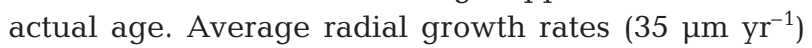
for the entire specimen and the average growth rate from the period $\sim 1950$ to $2002\left(45 \mu \mathrm{m} \mathrm{yr}^{-1}\right.$ ) (Roark et al. 2009) are consistent with earlier radiocarbon-based growth rate estimates (Roark et al. 2006).

Since the specimen studied by Roark et al. (2009) was one of the few live specimens that were collected intact, it provides the best opportunity to derive a linear growth rate estimate based on radiocarbon ages. This gold coral overgrew a bamboo coral (Fig. 2C) to a branch height of $700 \mathrm{~mm}$. The measured life span of the gold coral was $314 \pm 30 \mathrm{yr}$, resulting in a linear growth rate of $2.2 \pm 0.2 \mathrm{~mm} \mathrm{yr}^{-1}$. This is the fastest 
growth rate possible, as it assumes all the upward linear growth was in the gold coral while in fact a significant portion of the linear growth was in the overgrown bamboo coral. Some $21 \%$ of the measured diameter of the branch $\sim 220 \mathrm{~mm}$ up from the base was still comprised of the bamboo coral skeleton (Fig. 2C).

The projected linear growth rate from the radiocarbon data is close to the overall mean delta $(0.23 \mathrm{~cm}$ $\mathrm{yr}^{-1}$ ) seen in the marked field colonies. In the marked colonies there were only 6 positive differences that exceeded the measurement error; this may be due to variable or even sporadic growth. Assuming there is some environmental basis for this variability (e.g. variable food resource), the largest observed positive difference (15 $\mathrm{cm}$ in $7 \mathrm{yr}$ ) would derive a $2.14 \mathrm{~cm} \mathrm{yr}^{-1}$ growth rate. This is the most rapid outlier and it is still a third of the growth rate estimated using stem ring counts $\left(6.6 \mathrm{~cm} \mathrm{yr}^{-1}\right)$. Given that the majority of the marked colonies exhibited little change outside of the measurement uncertainties, the data support the very slow growth model indicated by the radiocarbon results. More time and greater resolution are needed to determine if growth pulses exist and to document their variability across the population.

\section{Ecological considerations}

Gold coral's slow growth and parasitic nature are important influences on the colony size and age frequency distribution of the gold coral community, especially considering that its host, bamboo coral, has been estimated to have a much shorter life span ( 70 to 120 yr) (Roark et al. 2005). The bamboo corals that were seen partially colonized by gold coral typically had gold coral encrusted on the lower portion of the colony. In 2 circumstances a bamboo colony was seen with an isolated spot of gold coral tissue growing midlevel on the host. Until the parasitic gold coral extends down to overgrow the base of the host, there is a risk the bamboo coral will die and topple and take the colonizing gold coral with it. The bamboo skeleton composition, i.e. carbonate segments connected by protein nodes, likely makes it more susceptible to toppling once the living tissue is lost. The mix of a slow-growing, long-lived parasitic coral on a faster-growing, shorter-lived host suggests there is some aspect of gold coral's life history that is yet unknown. Ideally, the colonizing gold coral tissue would have the ability to quickly secure portions of the host colony skeleton as it became available (e.g. host tissue lost to sea urchin predators), or better still, the ability to outcompete the living tissue of the host and take over the skeleton. Currently, only 2 field observations show bamboo skeleton covered with translucent gold tissue that might suggest a process of colonization by gold that is more rapid than its overall growth rate. Both of these colonies have been marked for future inspection. Since all the collected gold coral specimens had bamboo corals at their centers, it is clear that bamboo coral is the primary host. Bamboo coral's availability, recruitment and susceptibility to colonization are fundamental considerations when evaluating communities of gold coral.

Because of the parasitic nature of gold coral, it is conceivable that there might be multiple phases of growth: one for colonization and overgrowth of the bamboo host and another for extending its protein skeleton beyond the branch tips of the host. It is possible that height and condition of the bamboo coral host play a greater role than does the growth rate of gold coral in the size frequency of coral trees in a patch of gold coral.

\section{CONCLUSIONS}

Remeasurement of the 48 colonies marked in the field in prior years showed no discernable growth despite having as many as 9 yr elapse, indicating the growth of gold coral is much slower than linear estimates derived from ring counts. Because the study period was too short to validate current radiocarbon estimates, the present study characterized the variability in radiocarbon data with broad geographic sampling $(\mathrm{n}=23)$ across the study sites, showing average $( \pm \mathrm{SD})$ radial growth rates of $41 \pm 23 \mu \mathrm{m} \mathrm{yr}{ }^{-1}$ and average life spans of $950 \mathrm{yr}$. Using a crude linear radiocarbon growth rate of $2.2 \mathrm{~mm} \mathrm{yr}^{-1}$, it would take decades (total of $30 \mathrm{yr}$ ) for the colonies marked in the field to grow enough to be detected by our current measurement technique. The long life span of gold coral and its parasitic association with bamboo coral are an obvious focus for future study and will likely have important ecological implications for the distribution and persistence of gold coral communities.

Acknowledgements. Initial field marking of colonies was made possible with support from the National Undersea Research Program and the NOAA Office of Ocean Exploration. The 2007 dives to collect samples and remeasure colonies were supported by the Hawaii Fishery Disaster Relief Program FDRP grant no. 657781. The facilities and staff of the Hawaii Undersea Research Laboratory were essential to accomplishing the fieldwork and the success of the project. Access to sites in the Northwestern Hawaiian Islands was sanctioned by permit from the Papahānamokuākea National Marine Monument. Finally, this paper greatly benefitted from comments provided by E. Druffel, R. Grigg and 2 anonymous reviewers. 


\section{LITERATURE CITED}

Cohen J (1988) Statistical power analysis for the behavioral sciences, 2nd edn. Laurence Erlbaum Associates, Hillsdale, NJ

Connell J (1978) Diversity in tropical rain forests and coral reefs. Science 199:1302-1310

Druffel ERM, Griffin S, Witter A, Nelson E, Southon J, Kashgarian M, Vogel J (1995) Gerardia: Bristlecone pine of the deep-sea? Geochim Cosmochim Acta 59:5031-5036

Druffel ERM, Griffin S, Guilderson TP, Kashgarian M, Southon JR, Schrag DP (2001) Changes of subtropical North Pacific radiocarbon and correlation with climate variability. Radiocarbon 43:15-25

Goldberg WM (1991) Chemistry and structure of skeletal growth rings in the black coral Antipathes fiordensis (Cnidaria, Antipatharia). Hydrobiologia 216-217:403-409

Goodfriend GA (1997) Aspartic acid racemization and amino acid composition of the organic endoskeleton of the deep-water colonial anemone Gerardia: determination of longevity from kinetic experiments. Geochim Cosmochim Acta 61:1931-1939

Grange KR, Goldberg WM (1992) Chronology of black coral growth bands: 300 years of environmental history? In: Battershill CN, Schiel DR, Jones GP, Creese RG, MacDiamid $\mathrm{AB}$ (eds) Proc 2nd Int Temperate Reef Symp, Auckland, New Zealand. NIWA Marine, Wellington, p 169-174

Grigg RW (1965) Ecological studies of black coral in Hawaii. Pac Sci 19:244-260

Grigg RW (1974a) Distribution and abundance of precious corals in Hawaii. Proc 2nd Int Coral Reef Symp, Brisbane, p 235-240

Grigg RW (1974b) Growth rings: annual periodicity in two gorgonian corals. Ecology 55:876-881

Grigg RW (2002) Precious corals in Hawaii: discovery of a new bed and revised management measures for existing beds. Mar Fish Rev 64:13-20

Grigg RW (2004) Harvesting impacts and invasion by an alien species decrease estimates of black coral yield off Maui, Hawaii. Pac Sci 58:1-8

Hughen KA, Baille MGL, Bard E, Bayliss A and 23 others (2004) Marine04: marine radiocarbon age calibration, 26-0 ka BP. Radiocarbon 46:1059-1086

Marschal C, Garrabou J, Hermelin JG, Pichon M (2004) A new method for measuring growth and age in the pre- cious red coral Corallium rubrum (L.). Coral Reefs 23: 423-432

Opresko DM (2009) A new name for the Hawaiian antipatharian coral formerly known as Antipathes dichotoma (Cnidaria: Anthozoa: Antipatharia). Pac Sci 63:277-291

Parrish FA (2006) Precious corals and subphotic fish assemblages. Atoll Res Bull 543:425-438

Parrish FA (2007) Density and habitat of three deep-sea corals in the lower Hawaiian chain. In: George RY, Cairns SD (eds) Conservation and adaptive management of seamount and deep-sea coral ecosystems. Rosenstiel School of Marine and Atmospheric Science, University of Miami, FL

> Parrish FA, Abernathy K, Marshall GJ, Buhleier BM (2002) Hawaiian monk seals (Monachus schauinslandi) foraging in deep-water coral beds. Mar Mamm Sci 18:244-258

Roark EB, Guilderson TP, Flood-Page S, Dunbar RB, Ingram BL, Fallon SJ, McCulloch M (2005) Radiocarbon-based ages and growth rates of bamboo corals from the Gulf of Alaska. Geophys Res Lett 32:L04606, doi:10.1029/2004 GL021919

> Roark EB, Guilderson TP, Dunbar RB, Ingram BL (2006) Radiocarbon-based ages and growth rates of Hawaiian deep-sea corals. Mar Ecol Prog Ser 327:1-14

Roark EB, Guilderson TP, Dunbar RB, Fallon SJ, Shester GS, Mucciarone DA (2009) Extreme longevity in proteinaceous deep-sea corals. Proc Natl Acad Sci USA 106: 5204-5208

> Sherwood OA, Scott DB, Risk MJ (2006) Late Holocene radiocarbon and aspartic acid racemization dating of deep-sea octocorals. Geochim Cosmochim Acta 70:2806-2814

Siegel S, Castellan NJ (1988) Nonparametric statistics for the behavioral sciences, 2nd edn. McGraw-Hill, New York

Stuiver M, Braziunas TF (1993) Modeling atmospheric ${ }^{14} \mathrm{C}$ influences and ${ }^{14} \mathrm{C}$ ages of marine samples to $10,000 \mathrm{BC}$. Radiocarbon 35:137-191

Stuiver M, Polach HA (1977) Discussion and reporting of ${ }^{14} \mathrm{C}$ data. Radiocarbon 19:355-363

Stuiver M, Reimer PJ (1993) Extended ${ }^{14} \mathrm{C}$ database and revised CALIB V5.0 radiocarbon calibration program. Radiocarbon 35:215-230

Tracey DM, Neil H, Marriott P, Andrews AH, Calliet GM, Sanchez JA (2007) Age and growth of two genera of deepsea bamboo corals (family Isididae) in New Zealand waters. Bull Mar Sci 81:393-408 
Appendix 1. Gerardia sp. Radiocarbon summary of sample information $( \pm \mathrm{SE})$, outer and inner radiocarbon ages, calibrated median probability ages from the Calib 5.0 program, calculated life spans and radial growth rates of gold coral in the Hawaiian Archipelago. Median probability age is derived from the radiocarbon calibrations using a $\Delta \mathrm{R}$ of $-28 \pm 23{ }^{14} \mathrm{C}$ yr (Druffel et al. 2001), CALIB 5.0 (Stuiver \& Reimer 1993) and the Marine04 calibration data set (Hughen et al. 2004)

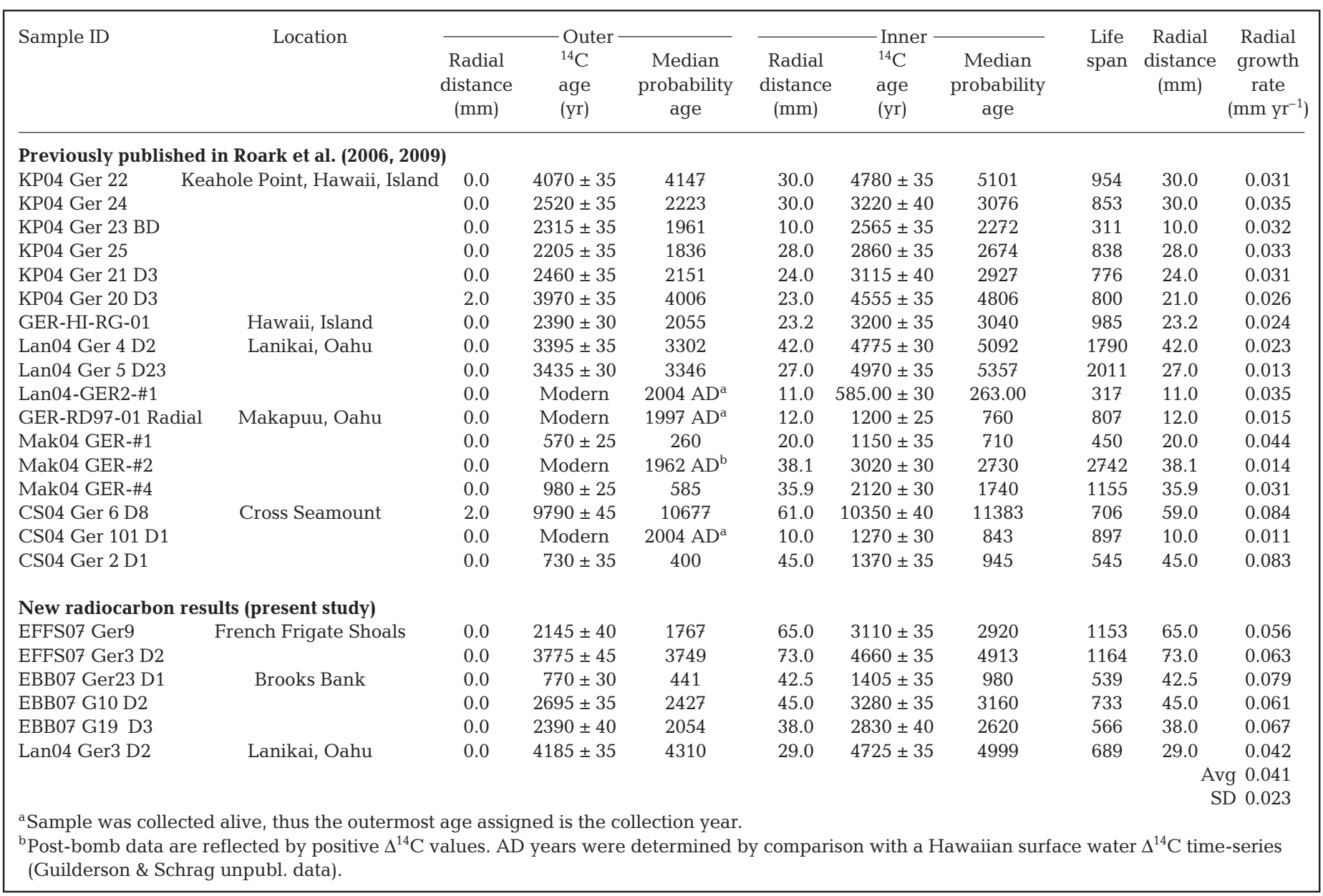

